\title{
Effect of Yogic Exercise on Emotional Maturity of B.Ed. Students
}

\author{
Dr. Mahesh Kumar Muchhal ${ }^{1 *}$, Arun Kumar ${ }^{2}$
}

\section{ABSTRACT}

The sample of the present study comprised 100 Students of B.Ed class from colleges of Ambala district. The post test experimental and control group design was followed. There were two groups (control group and experimental group) 50 students were assigned in each group. The experiment was conducted for 30 days with yoga exercise Shatkriyas (Kapalbhati and Trataka), Pranayamas (Anulom-Vilom, Shitali, Shitkari and Bhramari) and Meditation regularly in the morning. Emotional Maturity Scale by Yashvir Singh \& Dr. Mahesh Bhargava (1990) was used.

\section{Keywords: Yoga exercise and Emotional Maturity.}

The wealth of India, Yoga is one of the greatest gifts of India to the world. Part of daily routine for the Indians of yore, today yoga has become one of the most popular systems of health and healing, all over the world. It is also a spiritual pursuit for many seekers of truth. In the modern world, western countries like America use yoga as a tool for mental, physical and spiritual upliftment .Life is full of stress as a result of existence in the fast, mechanized and competitive way of life. Moreover modernization, urbanization, materialism, competition and ever changing trends of society tend to put stress on individuals of all age groups.

In the present circumstances, youth as well as children are facing difficulties in life. These difficulties are giving rise to many psychosomatic problems such as anxiety, tension, frustration and emotional upsets in day to day life. So the study of emotional life is now emerging as a descriptive science, comparable with anatomy it deals with an inter play of forces with intensities and quantities. Available tests are crude and measure chiefly the degree of dependence. But the test measures the difficult aspects of emotional maturity. As self-acceptance is an important aspect of maturity ways Wenkart, it must be preceded by acceptance from others. Emotional maturity is concerned primarily with self-control and expression. The teacher develops through a variety of experiences. For instance, the school can help the adolescents to arrange situations that will enable them to judge and evaluate their own behaviour. The school can provide a variety of supervised playground activities that permit children to free rather than rigidly prescribe art expression and help children take part in discussions in the classroom or in private conference.

\footnotetext{
${ }^{1}$ Associate Professor, Digamber Jain (PG) College Baraut, Baghpat (U.P)

${ }^{2}$ Assistant Teacher, P.S Belda Bujurg, Deoband Saharnapur.

*Responding Author

(C) 2015 I M Muchhal, A Kumar; licensee IJIP. This is an Open Access Research distributed under the terms of the Creative Commons Attribution License (http://creativecommons.org/licenses/by/2.0), which permits unrestricted use, distribution, and reproduction in any Medium, provided the original work is properly cited.
} 
Emotional maturity has not only a negative aspect but also positive one and emotional upsets in day-to-day life.

Actually, emotional maturity is not the only effective determinant of personality pattern but it also helps to control the growth of adolescent's development. The concept of mature emotional behaviour at any level is that which reflects the fruits of normal emotional development. A person who is able to keep his emotions under control, who is able to break delay and to suffer without self-pity might still be emotionally stunted and childish.

\section{REVIEW OF LITERATURE}

Emotional maturity is related to environmental factors (Kaur, 2000). Emotional maturity and intelligence are related (Kaur, 2001). Slum and urban areas children's have different emotional maturity (Muley, Patnam and Vasekar, 2003). Emotional expression skills of adolescents should be channelized for their effective mental health and personality development. Also postadolescent boys have higher emotional maturity than females (Chouhan and Bhatnagar, 2003). There exists a positive relationship between emotional maturity and self-concept of secondary level students (Gakhar, 2003). There exists some relationship between emotional intelligence and trait anxiety in adolescents (Markham, 2004). Emotional intelligence is related to ethical decision making (Scott, 2004).

\section{OBJECTIVES}

1 To study the emotional maturity of yoga students and Non-yoga students of B.Ed.

2 To compare the emotional maturity of yoga students and Non-yoga students of B.Ed.

\section{Hypotheses}

H1 There is no significant difference in Emotional maturity of B.Ed students of experimental and control groups at pre-test.

H2 There is no significant difference in Emotional maturity of B.Ed students of experimental and control groups at post-test.

H3 There is no significant difference in the mean reduced scores of Emotional maturity between B.Ed students of experimental and control groups.

\section{Design of the Study}

It was an experimental study based on randomized matching A pre-test, post-test, control group design with one experimental group was employed to conduct the present experimental study. Treatment was the independent variable and dependent variable is academic stress. Training in Yoga exercise Shatkriyas (Kapalbhati and Trataka), Pranayamas (Anulom-Vilom, Shitali, Shitkari and Bhramari) and Meditation was given to the experimental group for 30 days one hour in morning regularly. 


\section{Sample}

Sample of 100 B.Ed from colleges of Ambala Districts were taken in the present study. This was further categorized in to control group (50) and experimental group (50). We used randomize method to select the B. Ed students for data.

\section{Tools Used}

1. Emotional Maturity Scale by Yashvir Singh \& Dr. Mahesh Bhargava (1990)

2. Shatkriyas (Kapalbhati and Trataka)

3. Pranayamas (Anulom-Vilom, Shitali, Shitkari and Bhramari) \& Meditation

\section{RESULTS}

Table 1, Means, S.D.'s and t-ratios for pre-test and post-test scores on Emotional Maturity of the Experimental and Control Groups.

\begin{tabular}{|c|c|c|c|c|c|c|}
\hline \multirow{2}{*}{ Groups } & \multicolumn{3}{|c|}{ Pre-Test } & \multicolumn{3}{c|}{ Post-Test } \\
\cline { 2 - 6 } & Mean & S.D & 't' Value & Mean & S.D & 't' Value \\
\hline Yoga Students & 92 & 23.78 & \multirow{2}{*}{\begin{tabular}{c}
0.196 \\
\cline { 5 - 7 }
\end{tabular}} & 81.03 & 17.54 & \multirow{2}{*}{$2.146^{*}$} \\
\hline $\begin{array}{c}\text { Non-Yoga } \\
\text { Students }\end{array}$ & 91.07 & 23.45 & (NS) & & 23.179 & \\
\hline
\end{tabular}

* Significant at 0.05 level, N.S. - Not Significant

Table 2, Means, S.D's and t-ratios of total Mean reduced scores of Experimental and Control Groups on Emotional Maturity.

\begin{tabular}{|c|c|c|c|c|c|}
\hline Component & Groups & $\mathbf{N}$ & Mean & SD & 't' Value \\
\hline $\begin{array}{c}\text { Emotional } \\
\text { Maturity(Total) }\end{array}$ & Yoga Students & 50 & 10.97 & 7.081 & \multirow{2}{*}{$9.648^{* *}$} \\
\cline { 2 - 5 } & Non-Yoga Students & 50 & 1.22 & 0.958 & \\
\hline
\end{tabular}

**Significant at 0.01 level

\section{DISCUSSION}

Entries made in Table 1 Hypothesis H1 "There is no significant difference in Emotional maturity of B.Ed students of experimental and control groups at pre-test” was accepted. Hypothesis H2 "There is no significant difference in Emotional maturity of B.Ed students of experimental and control groups at post-test" was rejected in favour of the finding that yogic practices helped in improving of Emotional Maturity. 


\section{Effect of Yogic Exercise on Emotional Maturity of B.Ed. Students}

Entries made in Table 2 t-ratio for the mean reduced scores between the experimental and control groups on Emotional maturity was found to be significant at 0.01 level of confidence $(\mathrm{t}=9.648)$. Thus, H3 was rejected as the experimental group students who were exposed to yogic practices exhibited improvement Emotional maturity as compared to their counterparts of the control group.

\section{CONCLUSION}

On the behalf of above discussion we can say that yoga effects emotional maturity of the B.Ed students. We can emotionally stable through yoga practices can yoga effects our nervous system and glandular system which makes our emotionally mature. So yoga helps to improve emotional maturity.

\section{REFERENCE}

Bheema, M. (1988) The impact of emotional maturity and prolonged deprivation on indisciplined behaviour among university students in relation to their academic achievement. Unpublished doctoral thesis, Education, Kumaun University. In M.B. Buch (Editor) A Fifth Survey Research in Education, Baroda: CASE, M.S. University of Baroda.

Bhole, M.V. \& KaramKelkar, P.V. (1971) Effect of yoga training on vital capacity and breath holding time. Yoga mimansa, Vol.15, 19-26.

Chouhan, V.L and Bhatnagar, T. (2003) Assessing emotional maturity, emotional expression and emotional Quotient of adolescent male and female students, Journal of Community Guidance and Research, Vol. 20. No. (2), 157-167.

Cutler, S. E. (1996) Interrelationships between gender taxability and adult emotional maturity. Unpublished doctoral thesis, Dissertation Abstracts International, Vol. 57 (3), 2218.

Deepa, M. and Vasekar, J. (2003) Emotional maturity of school going children of slum and Urban Areas and the influencing factor. Journal of Community Guidance and Research, Vol. 20(1), 25-26.

Dhami, G.S. (1974) Intelligence, Emotional maturity and socio-economic status as factors Indicative of success in scholastic Achievement, Unpublished doctoral thesis, Panjab University, Chandigarh.

Gakhar, S.C. (2003) Emotional maturity of students of secondary stage. Journal of Indian Education, Vol. 20, No. (1), 100-106.

Ganguly, S.K. (1989) Immediate effect of kapalbhati on cardiovascular endurance. Indian Psychological Abstract, Vol. 28 (1), 1-7.

Gupta, P. (1989) A comparative study between male and female adolescent school going students on emotional maturity and achievement and achievement in co-and curricular activities. Unpublished doctoral thesis, Agra University, In M.B. Buch (Editor), A Fifth Survey of Research in Education, Baroda CASE, M.S. University of Baroda, 1987.

Kaur, J. (2000) Emotional maturity in relation to environmental factors. Unpublished M.Ed dissertation, Panjab University, Chandigarh. 
Kaur, M. (2001) A study of emotional maturity of adolescents in relation to intelligence, academic achievement and environmental catalysts, Unpublished doctoral thesis, Panjab University, Chandigarh.

Markham, T. (2004) Effects of positive emotional refocusing on emotional intelligence and autonomic recovery from stress in high school students. Unpublished doctoral thesis, Say Brook Graduate School and Research Center, Dissertation Abstracts International, Vol. 65 (90), 4889.

Pratap, V. (1971) Investigation on Tratka, collected papers on yoga, Lonavala, Kaivalyadhama, 16.

Sahu,R.J \& Bhole,M.V. (1983) Effect of three week Yogic training programme on psychomotor performance, Yoga Mimansa,22,59-62.

Swami, Satyananda (1996) Asana, Pranayama, Mudra, Bandha, Bihar Yoga Bharti Munger, Bihar.

Swami, Satyananda (1996) Asana, Pranayama, Mudra, Bandha, Bihar Yoga Bharti Munger, Bihar.

Swami, Sivananda (1945) Yoga Pradipika, Divine Life Publication, Rishikesh.

Swami, Sivananda (1945) Yoga Pradipika, Divine Life Publication, Rishikesh.

Tirth, Omanand (1960) Patanjal Yog Paradeep, Geeta Press Gorkhpur. 